\title{
5,6-Dihydroxyindole-2-Carboxylic Acid Oxidase
}

National Cancer Institute

\section{Source}

National Cancer Institute. 5,6-Dihydroxyindole-2-Carboxylic Acid Oxidase. NCI Thesaurus. Code C18271.

5,6-dihydroxyindole-2-carboxylic acid oxidase (537 aa, $\sim 61 \mathrm{kDa}$ ) is encoded by the human TYRP1 gene. This protein plays a role in melanin biosynthesis. 